\title{
Digitalization of the company's financial resources (by the example of Air Astana JSC)
}

\author{
Gulmira Kassenova1,*, Aizhan Zhamiyeva ${ }^{2}$, Aizhan Zhildikbayeva ${ }^{3}$, Raigul Doszhan ${ }^{1}$, \\ Kamilla Sadvakassova ${ }^{1}$ \\ ${ }^{1}$ Al-Farabi Kazakh National University, al-Farabi Ave. 71, 050040 Almaty, Kazakhstan \\ ${ }^{2}$ L.N. Gumilyov Eurasian National University, Satpayev Str. 2, 010008 Nursultan, Kazakhstan \\ ${ }^{3}$ Kazakh National Agrarian University, Abay Ave., 8, 050010 Almaty, Kazakhstan
}

\begin{abstract}
The article considers the problems of the digitalization and use of financial resources. There is an investigation on the factors of impact on the efficiency of developing, the sources and directions of entrepreneurs' financial resources allocation has been carried out in the article. For effective financial activity of the enterprise ways to improve the development and use of financial resources were suggested. The relevance of the topic is that the current situation of the companies will help to effectively analyze problem, build up the efficiency and effectiveness of its financial resources, activate the financial position of the financial institution. The financial resources of the enterprise are all part of the financial instruments for the formulation of non-qualified assets in all types, as well as the accounting of assets, capital and equity. The financial resources are designed to secure the financial budget, banks, insurance organizations, suppliers and goods; the cost of implementation of the expansion, reconstruction and modernization of production, the acquisition of new basic facilities.
\end{abstract}

\section{Introduction}

Digital transformation is the introduction of modern technologies in the business processes of an enterprise. This approach implies not only the installation of modern equipment or software, but also fundamental changes in management approaches, corporate culture, external communications. As a result, the productivity of each employee and the level of customer satisfaction are increased, and the company gains the reputation of a progressive and modern organization. Ford A. and Freeman V. (2016:38-47) said: "Digitalization of processes is relevant not only at the level of individual enterprises: entire industries choose digital transformation in order to move with the times and to progress along with the rest of society". Thus, the digital transformation of industry, retail, public sector and other areas is already changing the lives of every person and every company [1].

We have an expression from Samuel A.N. (2010:65-68): "Companies are fast or dead". In the digital economy, this phrase is more than relevant: if the company does not use the capabilities of modern technologies, does not adapt to the crazy pace and features of business,

\footnotetext{
* Corresponding author: guka_71@ mail.ru
} 
it will not be able to compete with those who already do [2]. "To be successful, you need to be fast and flexible" was noted by Douglas A. (2014:217) [3]. Digital transformation of business processes is aimed at ensuring that companies make decisions promptly, quickly adapt work to the requirements of the current moment and meet customer needs. Blundell R. (2004:689) believes that "financial resources are a financial condition characterized by, firstly, the balance and quality of the combining financial instruments, technologies and services used by the enterprise, and secondly, the resilience to external and internal threats, third, the ability of the financial system of the enterprise to ensure the realization of its financial interests, goals and objectives with sufficient amounts of financial resources" [4].

The purpose of this article is to study the theoretical and practical aspects of the digitalization and analysis of the effectiveness using of financial resources. To ensure the sustainable development of Kazakhstani economy we need to resolve a number of urgent problems, among which one of the principals is to increase the economic entities' financial resources productivity, because of the fundamental change the rules for their operation in the market today. Therefore, with a view to the effective management of the financial resources of enterprises, it is necessary to improve and develop existing ones, as well as develop new methodological approaches that consider the particular economic situation [5].

\section{Literature Review}

In the process of carrying out its financial and economic activities, the company carries out the formation of financial resources, which it then uses to meet its current operational needs, expand its activities, and investment activities.

The first step in the implementation of the financial mechanism for the formation of financial resources is the development of current production, investment and financial plans for the company in order to identify all sources of financial resources available to the company and to guarantee financial support for the company's activities with financial resources and fulfill the obligations of the company. In the process of formation and distribution of financial resources of the enterprise should be divided by their own and attracted sources of formation.

The use of attracted financial sources, along with its own, allows for a more rational use and preservation of the company's own working capital, to expand its activities, to implement investment projects in a timely manner. In the process of forming and distributing financial resources, one should not forget about creating financial reserves and special purpose funds in the form of highly liquid assets.

This is especially relevant in a changing market environment. This will ensure the stable operation of the enterprise and fulfill its obligations even during periods of recession and crisis.

An important step in ensuring the effectiveness of the formation and use of financial resources of an enterprise is the creation of an effective system of control over the observance of the financial and payment discipline of an enterprise. In implementing its financial and economic activity the enterprise carries out developing of financial resources, which further uses to ensure its ongoing operating needs, expanding its activities, investing [6]. Enterprise Financial Resources Developing Mechanism is shown in Figure 1.

The aim of enterprise's financial resources development mechanism in addition to determining the available sources of development, is, above all, effective allocation under conditions of acute shortage of financial resources and ensuring the sustainability and selffinancing of the enterprise, organization of financial activity of the enterprise in such a way as to regain the funds, invested in the company at the expense of profit and other financial resources and to implement fully the liabilities to suppliers of resources, financial institutions and the budget and provision the company's development [7]. 


\begin{tabular}{|l|l|l|}
\hline \multicolumn{2}{|c|}{ Enterprise Financial Resources Developing Mechanism } \\
\hline \hline \multicolumn{1}{|c|}{ Financial policy planning } \\
and making
\end{tabular}

Note: drawn up by the author based on Financial Statements of Air Astana JSC

Fig. 1. Enterprise Financial Resources Developing Mechanism.

\section{Materials and methods}

In this work were used methods of cognition, including methods of empirical (observation, comparison) and theoretical studies (analysis, synthesis, aggregation), scientific assessment. Modernization of the economy of the country, its regions and cities are inextricably linked with the state and development of enterprises. Results in any field of business depend on the availability and efficiency of use of financial resources, which are equal to the "circulatory system" that ensures the viability of the enterprise. Therefore, caring for financial resources is the starting point for the activities of any business entity. In a market economy, these issues are of paramount importance.

The financial resources of an enterprise are a set of additional attracted and reinvested by its own and borrowed capital in cash, intended to finance its future development in a deterministic planning period, the formation and use of which is controlled by it independently in accordance with the intended purpose, considering the risk factor. In principle, everything sources of financial resources of the enterprise can be represented as follows sequences: own financial resources and on-farm reserves; borrowed funds; attracted funds.

According to Berger A. (2010:231), "the essence of financial resources of enterprises is the ability to independently develop and implement a financial strategy in accordance with the objectives of the overall corporate strategy, in an uncertain and competitive environment" [8]. From the standpoint of Khan H. (2011), "digitalization of financial resources can be defined as the state of the most efficient use of information, financial indicators, liquidity and solvency, return on capital, within its limits".

I can also agree with the scientist Klomp J. (2014:112), who believe that digitalization of financial resources represents a state of the enterprise that allows ensuring financial 
equilibrium, stability, solvency, and liquidity of the enterprise in the long run; satisfies the needs of the enterprise in financial resources for the sustainable expansion; ensures sufficient financial independence; allows resisting existing and emerging dangers and threats that can cause financial damage to the enterprise, or undesirable change in the structure of capital, or forcing the company to liquidate; provides sufficient flexibility when making financial decisions; ensures the protection of the financial interests of the shareholders [9].

\section{Results and discussion}

The first step in implementation of the financial mechanism for developing of financial resources is formulation of current production, investment and financial plans for the enterprise in order to identify all sources of financial resources available to the enterprise and to guarantee funding for the enterprise's activities and fulfill the enterprise's obligations. In the process of developing and allocation of the financial resources of the enterprise they should be divided according to the own and attracted sources of development. Use the attracted financial resources along with own ones allows you to more efficiently use and keep their own working capital of the enterprise, expand its activities, implement investment projects in a timely manner. In the process of development and allocation of financial resources, one should not forget about creating financial reserves and special purpose trust funds in forms of highly liquid assets. This is particularly relevant in a changing market environment. This will ensure stable operations of the enterprise and fulfill its obligations even during periods of recession and crisis [10].

An important step in ensuring productivity of enterprise's financial resources is to create an effective system of control over the observance of the financial and payment discipline of an enterprise. Within this article the practice of developing financial resources of Kazakhstan's major airline company - Air Astana JSC shall be analyzed in detail. During the development of financing sources of the enterprise the peculiarities of functioning of the enterprises in the sector of aviation industry and the services provided by them should be considered. Aviation transportation activities associated with the implementation of a large number of works and services related not only to transportation of the passengers and freights, freight forwarding services, maintenance of air vehicles, transport service security [11].

In modern conditions of globalization and high rates of technological modernization, companies increasingly have to focus on attracting borrowed capital, including its alternative forms, such as leasing and factoring.

Table 1. Sources of formation of financial resources of the enterprise.

\begin{tabular}{|c|l|}
\hline \multirow{2}{*}{ Sources of financial resources } & - Borrowed funds; \\
& - Involved funds; \\
& - Budget financing; \\
& - Attraction of foreign capital \\
\hline Note: drawn up by the author based on Financial Statements of Air Astana JSC \\
\hline
\end{tabular}

For several years, the national airline Air Astana JSC has been expanding its own business and property through long-term leasing agreements. At the same time, the growth of the market and the development of the transportation network of Air Astana JSC require an increase in the efficiency of attracting and using available financial resources.

Over the past 10 years, the volume of the air transportation market in Kazakhstan has doubled and in 2018 amounted to 7.4 million passengers (in 2007 - more than 2.7 million passengers). In relation to the general transportation market in Kazakhstan, air travel now 
provides a larger share of passenger traffic than five years ago. In addition, the International Air Transport Association (IATA) predicts a twofold increase in global demand for passenger services over the next 20 years.

The company currently operates a fleet of 32 turbojet aircraft, including 3 from the Boeing aircraft family, 9 from the Embraer aircraft family, and 20 from the Airbus family. But a new long-term leasing agreement for five Embraer E190-E2 aircraft has already been signed. Deliveries are expected at the end of 2019. Embraer E190-E2 offers increased range and operational efficiency that will support the company's growing network and open up new market opportunities for it.

In the structure of sources of financial resources of Air Astana, a large proportion of borrowed funds, including long-term liabilities (61-68\%), current liabilities (20-24\%) (Figure 2). The share of own sources of financial resources in 2016 was $13 \%$, in 2016 it significantly decreased and amounted to $6.8 \%$. In 2018, the company increased the share of own sources of financing activities to $14.7 \%$.

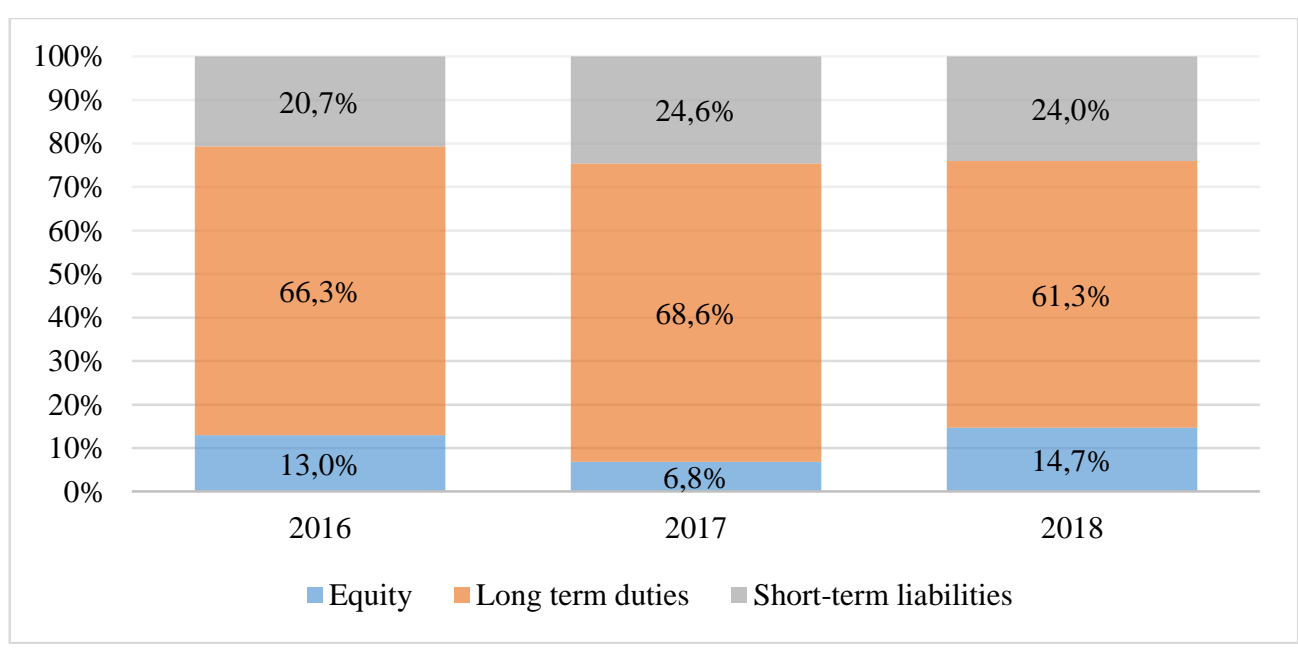

Note: drawn up by the author based on Financial Statements of Air Astana JSC

Fig. 2. Sources of financial resources of Air Astana JSC in 2016 - 2018, percentage.

Despite changes in the structure of borrowed capital of Air Astana JSC in recent years, other long-term financial liabilities, formed under financial leasing agreements for the purchase of aircraft, occupy the maximum share in the structure of borrowed capital. Their share in 2016 was $70.4 \%$, in 2018 it decreased to the level of $55.6 \%$ (Table 2).

Table 2. Analysis of the structure of borrowed capital of Air Astana JSC in 2016-2018.

\begin{tabular}{|l|c|c|c|c|c|}
\hline \multicolumn{1}{|c|}{ Sources of financing } & \multirow{2}{*}{2016} & \multirow{2}{*}{2017} & 2018 & \multicolumn{2}{c|}{ Changes } \\
\cline { 5 - 6 } & $0,0 \%$ & $2,3 \%$ & $2,1 \%$ & $+2,3 \%$ & $-0,2 \%$ \\
\hline Long-term loans & $70,4 \%$ & $62,9 \%$ & $55,6 \%$ & $-7,5 \%$ & $-7,3 \%$ \\
\hline $\begin{array}{l}\text { Other long-term financial } \\
\text { liabilities (Financial leasing) }\end{array}$ & $5,9 \%$ & $7,2 \%$ & $12,0 \%$ & $+1,4 \%$ & $+4,8 \%$ \\
\hline Long-term reserves & $0,0 \%$ & $1,2 \%$ & $2,2 \%$ & $+1,2 \%$ & $+0,9 \%$ \\
\hline Deferred tax liabilities & $0,0 \%$ & $0,3 \%$ & $0,3 \%$ & $+0,3 \%$ & $0,0 \%$ \\
\hline Short-term loans &
\end{tabular}




\begin{tabular}{|l|c|c|c|c|c|}
\hline $\begin{array}{l}\text { Other current financial } \\
\text { liabilities }\end{array}$ & $7,6 \%$ & $7,7 \%$ & $7,9 \%$ & $+0,1 \%$ & $+0,2 \%$ \\
\hline $\begin{array}{l}\text { Short-term trading and other } \\
\text { payables }\end{array}$ & $6,9 \%$ & $7,4 \%$ & $7,7 \%$ & $+0,5 \%$ & $+0,3 \%$ \\
\hline Short term reserves & $3,1 \%$ & $3,8 \%$ & $2,6 \%$ & $+0,7 \%$ & $-1,2 \%$ \\
\hline Other short term liabilities & $6,2 \%$ & $7,2 \%$ & $9,6 \%$ & $+1,0 \%$ & $+2,4 \%$ \\
\hline Total borrowed capital & $100,0 \%$ & $100,0 \%$ & $100,0 \%$ & & \\
\hline
\end{tabular}

In 2012-2014, the company acquired eleven aircraft under a fixed-rate financial lease. The lease term for each aircraft is twelve years. The company has the ability to purchase each aircraft at a nominal price at the end of the lease term. Loans issued by financial institutions to the lessor in respect of six Airbus aircraft that were delivered during 2012 and 2013 are under the guarantee of the European Export Credit Agencies, three Boeing 767 that were delivered in 2013 and 2014 are under the guarantee US Export Import Bank, and two Embraer, delivered in 2012 and 2013, are under the guarantee of the Brazilian Development Bank. The Company's financial lease obligations are secured by the lessor's right to leased assets. These assets have a book value in 2018 - 68,671,498 thousand tenge (2016: $74,352,809$ thousand tenge).

The company's liabilities in 2016 included the current value of financial lease obligations in the amount of 13,796 million tenge and the long-term part of the obligations in the amount of 127,569 million tenge. In 2016, the long-term part of liabilities decreased by $12.3 \%$ and in 2018 another $16.5 \%$.

In 2018, the share of long-term reserves in the structure of borrowed capital, which are intended for the maintenance of aircraft acquired under financial leasing contracts, increased by 1.5 times. In accordance with the terms of the operating lease, Air Astana JSC is obliged to conduct and pay for the standard repair and maintenance procedures for the aircraft as it operates and return the aircraft to the lessor in a satisfactory condition at the end of the lease term.

The share of other short-term liabilities of the company in the reporting period remained at the level of $7.6-7.9 \%$. The share of short-term trade and other payables increased from $6.9 \%$ in 2016 to $7.7 \%$ in 2018 .

Thus, the main source of financing for the activities of Air Astana JSC are long-term financial obligations related to financial leasing agreements concluded for the purchase of aircraft. Their share in 2018 is more than $55 \%$ of the total financial resources. We will analyze the effectiveness of the use of financial resources of the company by the method of analysis of financial ratios (Table 3).

Table 3. Coefficient analysis of the efficiency of use of financial resources of Air Astana JSC.

\begin{tabular}{|l|c|c|c|c|c|}
\hline \multirow{2}{*}{ Indicators } & \multirow{2}{*}{2016} & 2017 & 2018 & \multicolumn{2}{c|}{ Changes } \\
\cline { 5 - 7 } & & & & $2017 / 2016$ & $2018 / 2017$ \\
\hline Absolute liquidity ratio & 1,660 & 0,921 & 1,043 & $-0,739$ & $+0,122$ \\
\hline Total liquidity ratio & 2,063 & 1,371 & 1,494 & $-0,692$ & $+0,123$ \\
\hline Capitalization ratio & 6,706 & 13,652 & 5,820 & $+6,946$ & $-7,832$ \\
\hline $\begin{array}{l}\text { Coefficient of independence } \\
\text { (autonomy) }\end{array}$ & 0,130 & 0,068 & 0,147 & $-0,062$ & $+0,078$ \\
\hline Financial tension ratio & 0,870 & 0,932 & 0,853 & $+0,062$ & $-0,078$ \\
\hline Financial stability ratio & 0,793 & 0,754 & 0,760 & $-0,039$ & $+0,006$ \\
\hline Return on assets & 0,050 & $-0,067$ & 0,065 & $-0,117$ & $+0,132$ \\
\hline Return on equity & 0,383 & $-0,985$ & 0,445 & $-1,369$ & $+1,430$ \\
\hline
\end{tabular}


Return on sales

\begin{tabular}{l|l}
0,066 & $-0,064$ \\
\hline
\end{tabular}

\begin{tabular}{l|l}
0,055 & $-0,130$
\end{tabular}

$+0,118$

Note: drawn up by the author based on Financial Statements of Air Astana JSC

Analysis of the calculated indicators shows a satisfactory liquidity of the company in the period under consideration, with a rather high risk of losing financial stability. At the same time, in 2018, the company showed an increase in return on equity and return on assets compared to 2016. In 2017, Air Astana JSC had a difficult financial situation due to impairment losses on financial assets.

Thus, the existing structure of financial resources of Air Astana JSC allows to increase the efficiency of financial resources management with skillful financial risk management.

Modern conditions of globalization and technological modernization of the domestic economy put at the forefront issues of efficient use and management of financial resources of enterprises and organizations of various spheres. Effective management of financial resources allows not only to identify their optimal sources of attraction, but also to distribute financial resources so that the company can improve the efficiency of its activities as a whole.

Also, the process of providing services by air entities is influenced destination network status, optimized speed, the ability to ensure continuity of service delivery, capacity of moving with specified parameters of flight personnel at any time of the year and under any weather conditions, level of services. Let's take a look at the trend and structure of assets of Air Astana JSC according to Table 4.

Table 4. Trend and structure of assets of Air Astana JSC for 2018-2016, million tenge.

\begin{tabular}{|c|c|c|c|c|c|c|c|c|}
\hline \multirow{2}{*}{ Article title } & \multicolumn{2}{|c|}{2016} & \multicolumn{2}{|c|}{2017} & \multicolumn{2}{|c|}{2018} & \multicolumn{2}{|c|}{$\begin{array}{c}\text { Change } \\
2018-2016\end{array}$} \\
\hline & $\begin{array}{l}\text { million } \\
\text { tenge }\end{array}$ & $\%$ & $\begin{array}{l}\text { million } \\
\text { tenge }\end{array}$ & $\%$ & $\begin{array}{c}\text { million } \\
\text { tenge }\end{array}$ & $\%$ & $\begin{array}{l}\text { million } \\
\text { tenge }\end{array}$ & $\%$ \\
\hline Long-term assets & 101,610 & 48.77 & 101,672 & 53.28 & 101,553 & 47.81 & -56 & $-0,06$ \\
\hline Fixed assets & 91,604 & 43.97 & 90,395 & 47.37 & 90,359 & 42.54 & $-1,245$ & -1.36 \\
\hline Intangible assets & 235 & 0.11 & 1,049 & 0.55 & 934 & 0.44 & 699 & 296.99 \\
\hline $\begin{array}{lll}\begin{array}{l}\text { Prepayments } \\
\text { current assets }\end{array} & \text { for } & \text { non- } \\
\end{array}$ & 3,514 & 1.69 & 3,038 & 1.59 & 3,120 & 1.47 & -394 & -11.21 \\
\hline Guarantee deposits & 5,227 & 2.51 & 5,133 & 2.69 & 5,937 & 2.79 & 710 & 13.58 \\
\hline $\begin{array}{l}\text { Trade and other accounts } \\
\text { receivables }\end{array}$ & 326 & 0.16 & 2,058 & 1.08 & 1,202 & 0.57 & 877 & 269.39 \\
\hline Current assets & 106,741 & 51.23 & 89,158 & 46.72 & 110,878 & 52.19 & 4,136 & 3.87 \\
\hline Inventories & 10,267 & 4.93 & 13,761 & 7.21 & 12,593 & 5.93 & 2,326 & 22.65 \\
\hline Advances made & 5,388 & 2.59 & 7,524 & 3.94 & 11,705 & 5.51 & 6,317 & 117.24 \\
\hline Income tax prepayment & 257 & 0.12 & 261 & 0.14 & 261 & 0.12 & 4 & 1.59 \\
\hline $\begin{array}{l}\text { Trade and other accounts } \\
\text { receivables }\end{array}$ & 7,088 & 3.4 & 7,349 & 3.85 & 8,395 & 3.95 & 1,307 & 18.44 \\
\hline Other taxes prepaid & 2,536 & 1.22 & 5,435 & 2.85 & 6,387 & 3.01 & 3,851 & 151.84 \\
\hline Guarantee deposits & 9,640 & 4.63 & 11,646 & 6.1 & 10,891 & 5.13 & 1,251 & 12.98 \\
\hline Bank deposits & 53,722 & 25.78 & 33,187 & 17.39 & 2 & 0 & $-53,720$ & -100 \\
\hline Cash and cash equivalents & 17,812 & 8.55 & 9,994 & 5.24 & 60,643 & 28.55 & 42,831 & 240.46 \\
\hline Total assets & 208,351 & 100 & 190,830 & 100 & 212,431 & 100 & 4,080 & 1.96 \\
\hline
\end{tabular}

As shown in table, the assets of the company under consideration, Air Astana JSC, for the reporting period grew by 4.1 billion. tenge, or $1.96 \%$ amounted to 212.4 billion. tenge in the year 2018. The main increase is accounted for by current assets, increments of which for the period 2016-2018 were 3.87 \%. Trend in assets of Air Astana JSC is shown in Figure 3. With regard to asset profile of Air Astana JSC, it should be noted that over the past three years it has hardly changed - throughout 2016-2018 years the largest relative share in the 
structure of assets of Air Astana JSC is constituted of current assets (51.23\% in 2016 year, $52.19 \%$ in 2018).

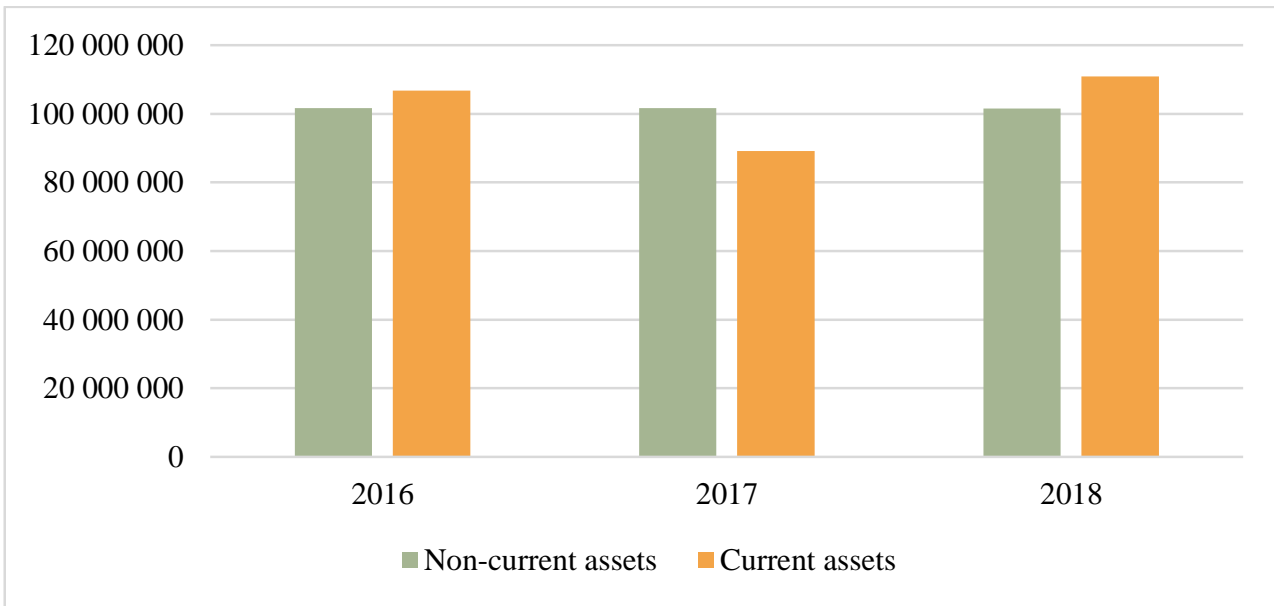

Note - Drawn up by the author based on Financial Statements of Air Astana JSC

Fig. 3. The dynamics of changes in assets of Air Astana JSC for 2016-2018, thousand tenge.

A high relative share of current assets can be explained by industry feature of JSC Air Astana, the presence on the company's balance sheet of a large amount of cash, inventories and accounts receivable. On long-term assets, a decrease in their relative share from $48.77 \%$ in the year 2016 down to $47.81 \%$ in the year 2018 .

Further let us analyze changes in sources of asset formation - in equity and liabilities of JSC “Air Astana” for 2016-2018 according to Table 5.

Table 5. Trend in shareholders ' equity and liabilities of Air Astana JSC for 2016-2018, million tenge.

\begin{tabular}{|l|c|c|c|c|c|c|c|c|}
\hline \multirow{2}{*}{ Article title } & \multicolumn{2}{|c|}{2016} & \multicolumn{2}{c|}{2017} & \multicolumn{2}{c|}{2018} & \multicolumn{2}{c|}{$\begin{array}{c}\text { Change in } \\
2018-2016\end{array}$} \\
\cline { 2 - 10 } & $\begin{array}{c}\text { million } \\
\text { tenge }\end{array}$ & $\%$ & $\begin{array}{c}\text { million } \\
\text { tenge }\end{array}$ & $\%$ & $\begin{array}{c}\text { million } \\
\text { tenge }\end{array}$ & $\%$ & $\begin{array}{c}\text { million } \\
\text { tenge }\end{array}$ & $\%$ \\
\hline Equity & 27,036 & 12.98 & 13,024 & 6.82 & 24,573 & 11.57 & $-2,464$ & -9.11 \\
\hline Share capital & 2,502 & 1.2 & 2,502 & 1.31 & 2,502 & 1.18 & 0 & 0 \\
\hline Additional paid-in capital & 49 & 0.02 & 49 & 0.03 & 49 & 0.02 & 0 & 0 \\
\hline $\begin{array}{l}\text { Provision for hedging } \\
\text { instruments, net of tax }\end{array}$ & $-30,744$ & -14.76 & $-26,741$ & -14.01 & $-25,943$ & -12.21 & 4,801 & -15.62 \\
\hline Retained earnings & 55,230 & 26.51 & 37,215 & 19.5 & 47,966 & 22.58 & $-7,264$ & -13.15 \\
\hline Long-term liabilities & 27,036 & 12.98 & 13,024 & 6.82 & 129,905 & 61.15 & 102,869 & 380.48 \\
\hline Loans & 0 & & 4,014 & 2.1 & 3,625 & 1.71 & 3,625 & \\
\hline Finance lease liability & 127,569 & 61.23 & 111,818 & 58.6 & 103,994 & 48.95 & $-23,575$ & -18.48 \\
\hline Deferred tax liability & 0 & & 2,213 & 1.16 & 2,909 & 1.37 & 2,909 & \\
\hline $\begin{array}{l}\text { Provision for } \\
\text { maintenance }\end{array}$ & 10,652 & 5.11 & 12,850 & 6.73 & 19,376 & 9.12 & 8,724 & 81.9 \\
\hline Current liabilities & 43,093 & 20.68 & 46,910 & 24.58 & 57,953 & 27.28 & 14,860 & 34.48 \\
\hline Loans & 0 & & 544 & 0.28 & 541 & 0.25 & 541 & \\
\hline Finance lease liability & 13,796 & 6.62 & 13,749 & 7.2 & 14,234 & 6.7 & 438 & 3.17 \\
\hline Deferred income & 11,160 & 5.36 & 12,742 & 6.68 & 16,856 & 7.93 & 5,696 & 51.03 \\
\hline
\end{tabular}




\begin{tabular}{|l|c|c|c|c|c|c|c|c|}
$\begin{array}{l}\text { Provision for aircraft } \\
\text { maintenance }\end{array}$ & 5,600 & 2.69 & 6,747 & 3.54 & 5,831 & 2.75 & 231 & 4.13 \\
\hline Accounts payable & 12,476 & 5.99 & 13,129 & 6.88 & 20,490 & 9.65 & 8,014 & 64.24 \\
\hline Total liabilities & 181,315 & 87.02 & 177,806 & 93.18 & 187,858 & 88.43 & 6,543 & 3.61 \\
\hline Total Equity and Liabilities & 208,351 & 100 & 190,830 & 100 & 212,431 & 100 & 4,080 & 1.96 \\
\hline Note: drawn up by the author based on Financial Statements of Air Astana JSC \\
\hline
\end{tabular}

The data in the table show that a significant reduction in the equity capital of Air Astana JSC for 2016-2018 - for three years, the capital of the company under interest decreased by $9.11 \%$. Moreover, the main decrease is accounted for retained net profit, the amount of which has dropped from 55.2 billion tenge in 2016 to 48 billion in the year 2018 .

Long-term liabilities over the past three years significantly increased by 102.9 billion tenge and at the end of the period totaled 129.9 billion tenge. Thus, over the past three years, there has been an increase in long-term liabilities by more than 4 times. The amount of current liabilities also has risen from 43 billion tenge in 2016 to 58 billion tenge in the year 2018 . These changes in short-term liabilities are mainly associated with changes in the item "Shortterm trade and other payables", the amount of which for the last three years has increased by 8 billion tenge or by $64.24 \%$. Analysis of liabilities side of the balance-sheet showed changes in the structure, in terms of reducing the equity percent from 12.98 in 2016 to 11.57 with a significant increase in the relative share of long-term and short-term commitments.

The observed downward trend in relative share of equity and growth in debt capital reveals risk of solvency loss and financial difficulties, as well as the risk of further losses due to significant debt payments for the company (Kupeshova, 2014:480). In addition, exceeding growth of debt capital indicates whether the company depends from external financing. A high relative share of debt capital in the turnover of an organization is negative and suggests that the whole organization's working capital, as well as part of the non-current assets is based on sources of borrowed funds. Moreover, it should be noted a significant increase in accounts payable in the year 2018. Thus, certain negative trends in the structure of the balance sheet of JSC "Air Astana", namely despite the growth in assets, a decrease in equity and growth in debt capital are observed. A significant relative share of debt capital and its growth over the past three years showed that the company under interest has risk losing the financial stability during the reporting period.

To assess performance of Air Astana JSC according to Statement of revenues and expenditures, let us analyze the changes in the financial results of the company JSC Air Astana for 2016-2018 according to data in Table 6.

Table 6. Trend in the financial results of JSC Air Astana for 2016-2018, million tenge.

\begin{tabular}{|l|c|c|c|c|c|}
\hline \multirow{2}{*}{ Line item } & \multirow{2}{*}{2016} & \multirow{2}{*}{2017} & \multirow{2}{*}{2018} & \multicolumn{2}{c|}{ Change in 2018-2016 } \\
\cline { 5 - 6 } & & & & & million KZT \\
\hline Income & & & & & \\
\hline Passenger operations & 156,038 & 201,849 & 175,982 & 19,944 & 12.78 \\
\hline Cargo and mail & 4,313 & 5,367 & 4,480 & 167 & 3.88 \\
\hline Other income & 3,308 & 5,270 & 5,512 & 2,204 & 66.61 \\
\hline Total income & 163,660 & 212,486 & 185,974 & 22,315 & 13.63 \\
\hline Total operating expenses & 158,862 & 199,524 & 169,914 & 11,052 & 6.96 \\
\hline Operating profit & 4,798 & 12,962 & 16,060 & 11,262 & 234.73 \\
\hline Financial income & 1,653 & 2,643 & 2,145 & 492 & 29.76 \\
\hline Financial expense & 5,142 & 22,608 & 2,741 & 2,401 & -46.69 \\
\hline Exchange gain/(loss), net & 11,935 & $-3,916$ & 1,700 & $-13,635$ & -114.24 \\
\hline (Loss)/profit before tax & 13,244 & $-10,918$ & 13,764 & 520 & 3.92 \\
\hline Income tax expenses & 2,882 & 1,916 & 3,013 & -132 & 4.56 \\
\hline
\end{tabular}




\begin{tabular}{|l|c|c|c|c|c|} 
(Loss)/profit for the year & 10,363 & $-12,834$ & 10,751 & 388 & 3.75 \\
\hline $\begin{array}{l}\text { Other comprehensive } \\
\text { income/(loss) for the year, net of } \\
\text { income tax }\end{array}$ & $-30,744$ & 4,003 & 798 & 31,542 & -102.59 \\
\hline
\end{tabular}

As shown in table, operating profit of Air Astana JSC for last three years has risen to $13.63 \%$ and reached 186 billion tenge in the year of 2018 . The increase was mainly due to an increase in passenger revenue (Figure 4).

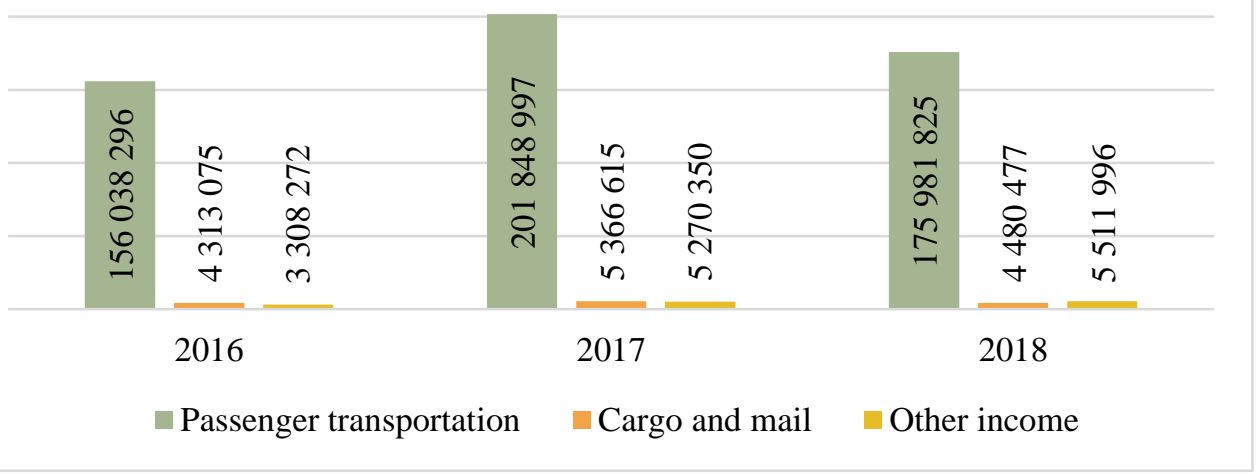

Note: drawn up by the author based on Financial Statements of Air Astana JSC

Fig. 4. Trend of Air Astana JSC incomes for the period of 2016-2018 thous. tenge

Over the past 3 years the income structure of Air Astana JSC has not undergone significant changes. Passenger operations amount to $95 \%$ of total revenue and remain the main source of income of the company. The remaining 5\% are accounted for income from cargo and mail transportation (3\%), as well as other ancillary income $(2 \%)$.

Table 7. Operating statistics of Air Astana JSC for 5 years.

\begin{tabular}{|c|c|c|c|c|c|c|c|}
\hline \multirow{2}{*}{ Line item } & \multirow{2}{*}{2014} & \multirow{2}{*}{2015} & \multirow{2}{*}{2016} & \multirow{2}{*}{2017} & \multirow{2}{*}{2018} & \multicolumn{2}{|c|}{$\begin{array}{c}\text { Change } \\
2018-2014\end{array}$} \\
\hline & & & & & & Absolute & $\begin{array}{l}\text { relative, } \\
\text { as } \%\end{array}$ \\
\hline The passengers carried, million & 3.25 & 3.68 & 3.77 & 3.86 & 3.75 & 0.5 & 15.4 \\
\hline Domestic & 1.99 & 2.12 & 2.18 & 2.28 & 2.09 & 0.1 & 5.0 \\
\hline International & 1.26 & 1.56 & 1.59 & 1.58 & 1.66 & 0.4 & 31.7 \\
\hline Transit & 0.09 & 0.19 & 0.20 & 0.19 & 0.31 & 0.22 & 244.4 \\
\hline $\begin{array}{l}\text { Passenger-kilometers performed, } \\
\text { billion }\end{array}$ & 6.40 & 7.45 & 7.55 & 7.78 & 7.81 & 1.41 & 22.0 \\
\hline Domestic & 2.33 & 2.52 & 2.57 & 2.77 & 2.55 & 0.22 & 9.4 \\
\hline International & 4.06 & 4.93 & 4.98 & 5.01 & 5.26 & 1.2 & 29.6 \\
\hline $\begin{array}{l}\text { Limit of passenger-kilometers, } \\
\text { billion }\end{array}$ & 9.47 & 11.40 & 11.67 & 12.41 & 12.72 & 3.25 & 34.3 \\
\hline Domestic & 3.28 & 3.55 & 3.71 & 4.17 & 3.95 & 0.67 & 20.4 \\
\hline International & 6.19 & 7.85 & 7.96 & 8.24 & 8.76 & 2.57 & 41.5 \\
\hline
\end{tabular}




\begin{tabular}{|l|c|c|c|c|c|c|c|}
\hline Load factor, \% & $68 \%$ & $65 \%$ & $65 \%$ & $63 \%$ & $61 \%$ & -0.07 & -10.3 \\
\hline Domestic & $71 \%$ & $71 \%$ & $69 \%$ & $66 \%$ & $65 \%$ & $-0,06$ & -8.5 \\
\hline International & $66 \%$ & $63 \%$ & $63 \%$ & $61 \%$ & $60 \%$ & -0.06 & -9.1 \\
\hline $\begin{array}{l}\text { Cargo, mail and excess baggage, } \\
\text { thous. tons }\end{array}$ & 22.1 & 23.8 & 19.0 & 16.6 & 16.6 & -5.5 & -24.9 \\
\hline $\begin{array}{l}\text { Tonne-kilometres performed, } \\
\text { million }\end{array}$ & 652 & 753 & 748 & 762 & 767 & 115 & 17.6 \\
\hline
\end{tabular}

Operating expenses of the Company, denominated in national currency, showed an increase of $6.96 \%$ from 158,861 million tenge in 2016 to 169,914 million tenge in the year of 2018. Since the bulk of Company's costs is set up in foreign exchange, change in the average exchange rate of tenge to dollar compared with the previous year had an impact on the growth of costs denominated in tenge. Along with depreciation of national currency, the increase in operating costs of the company affected the Company's activities on implementation of projects related to business expansion.

The company's commitment to high standards and values such as security, providing high quality service requires continuous investment in innovation and development. Net profit for 2018 increased by $156.7 \%$ up to 11.5 billion tenge compared to 2016 . Since the first flight of Almaty-Astana in 2002, Air Astana has been continuously developing and making every effort to become the best airline company in Kazakhstan and the CIS.

Impressive results over the past 15 years show that these purposes are achieved, because the company was able to establish a reliable airline carrier with high standards of security and an excellent level of customer service through a continuous commitment to ensure high efficiency.

During the year 2018 the company transported approximately 3.7 million passengers, that in an average makes more than 10,000 people a day. This figure shows a slight decrease to $3 \%$ compared to the year 2016 , mainly as a result of the $8 \%$ reduction in passenger traffic for domestic flights.

This decline was due to several fundamental factors such as a decrease of $5 \%$ in the number of limiting passenger-kilometers for domestic flights, compared to the year 2016, the depreciation of national currency and the rate of development of Kazakhstani air transportation market. In recent years there has been an increase in competition in the domestic air service by local airline carriers as Air Qazaq, Bek Air and Scat, reducing the share of Air Astana JSC in the domestic market, but it still remains the largest carrier in comparison with other Kazakhstani ones.

Thus, in general, the analysis shows positive trends in the financial condition of the company under investigation - there has been an increase in revenue and net profit for the last three years.

Investigation of interrelationship of structure financing sources of Air Astana JSC and its performance results showed a significant dependence of Company's performance from the structure of funding sources (Ghosh, 2016:58). The investigation found that:

- change the capital structure significantly affects the financial results; increasing the share of borrowed financial resources in the total amount of long-term sources leads to increased unpredictability of net profits change; at high values of the effect of the financial leverage the relationship between net profit and earnings before interest and taxes has become increasingly non-linear;

- capital structure optimization problem cannot be solved by building models of indifference points (equilibrium). Such models are based on operating rates of past activity of enterprises and only reflect the dependence of profit and profitability and the methods of financing used. The result of their analysis is to identify the capital structure, providing a condition in which financing options to compare the activities are of equal benefit [12]. 
For the enterprise attraction of a funding source for investment projects is associated with certain costs: issue of new shares requires dividend payments to shareholders; issue of bondsinterest payments; taking out a loan - paying interest on them, use of leasing - paying remuneration to the lessor, etc. Therefore, to carry out its investment activities Air Astana JSC must choose the optimal financing option (Table 8).

Table 8. Comparative characteristics of external financing sources for funding investment activity of the enterprise.

\begin{tabular}{|c|c|c|}
\hline Type of funding & Advantages & Disadvantages \\
\hline 1 & 2 & 3 \\
\hline $\begin{array}{c}\text { Public } \\
\text { placement of } \\
\text { shares }\end{array}$ & $\begin{array}{ll} & \text { Obtaining significant equity } \\
\text { - } & \text { Assets liquidity provision } \\
\text { - No need to pay debts } \\
\text { - No additional collateral } \\
\text { (guarantees) required }\end{array}$ & $\begin{array}{l}\text { - Significant issue costs and placement } \\
\text { provision are required } \\
\text { - Regulations on emissions by the } \\
\text { control bodies of the securities market. }\end{array}$ \\
\hline $\begin{array}{l}\text { Corporate } \\
\text { bonds }\end{array}$ & $\begin{array}{l}\text { - Interest rate is usually fixed } \\
\text { - Percentage is deducted from } \\
\text { taxable income } \\
\text { - Can be perceived as an } \\
\text { additional Owners' equity }\end{array}$ & $\begin{array}{l}\text { - Availability to use by large companies } \\
\text { - Regulations on emissions by the } \\
\text { governing bodies of the securities market } \\
\text { - High interest rates are possible }\end{array}$ \\
\hline $\begin{array}{l}\text { Credit line for } \\
\text { banks }\end{array}$ & $\begin{array}{l}\text { - Independence in the use of } \\
\text { funds received } \\
\text { - Efficiency of the process of } \\
\text { cash receiving }\end{array}$ & $\begin{array}{l}\text { - Lending period rarely exceeds } 3 \text { years } \\
\text { - Need to provide collateral; } \\
\text { - Limitation for a loan and possible high } \\
\text { interest rates }\end{array}$ \\
\hline State funding & $\begin{array}{l}\text { - Smaller amounts of sum } \\
\text { payable in satisfaction with longer } \\
\text { periods; } \\
- \text { Percentage is deducted from } \\
\text { the taxable profit }\end{array}$ & $\begin{array}{l}\text { - Limitation of the funds provided } \\
\text { - funds received must be spent for the } \\
\text { intended purpose. }\end{array}$ \\
\hline Leasing & $\begin{array}{l}\text { - It does not require immediate } \\
\text { payment and allows to develop a } \\
\text { convenient financing scheme } \\
\text { - It allows an enterprise that does } \\
\text { not have substantial financial } \\
\text { resources to launch a major project } \\
\text { - does not increase the debt in the } \\
\text { balance sheet and does not affect } \\
\text { the leverage ratio. }\end{array}$ & $\begin{array}{l}\text {-In rare cases additional collateral is } \\
\text { required. }\end{array}$ \\
\hline $\begin{array}{c}\text { Project } \\
\text { financing }\end{array}$ & -Receipt of substantial funds & - Primarily large-scale projects are funded \\
\hline
\end{tabular}

Solution of the task on developing structure of financing sources for of investment activity of Air Astana JSC with regard to requirements to optimality involves the development and implementation of finance and investment approach, which, unlike the traditional ones, considers maximizing the investment value of an enterprise as an optimization criterion (Malady, 2016:389).

In the course of its activity the enterprise may use different sources of financing for investment processes and use the known formula for calculating the value of their use. But there is a fairly new method of providing investment projects such as IPO. As a rule, the IPO refers to primary (in the public market the company's shares at the time of placement do not circulate) public (among an indefinitely large number of institutional and private investors) placement of shares. 
Advantages of IPO over other sources of financial resources developing are presented in Table 9.

Table 9. Advantages of IPO over other sources of financial resources developing.

\begin{tabular}{|l|l|}
\hline \multicolumn{1}{|c|}{ Funding source } & \multicolumn{1}{c|}{ Advantages of IPO } \\
\hline Retained earnings & $\begin{array}{l}\text { Large one-time equity inflow. Independence from future economic } \\
\text { conditions (business outlook) }\end{array}$ \\
\hline $\begin{array}{l}\text { Budget funds and } \\
\text { government loans }\end{array}$ & Efficiency of resource flows without time-consuming bureaucracy. \\
\cline { 2 - 2 } Bank loans & $\begin{array}{l}\text { Lack of commitment (including social programs) } \\
\text { payments }\end{array}$ \\
\hline Bonded loans & $\begin{array}{l}\text { No obligation to service the loan. for an unlimited period for equity } \\
\text { raising }\end{array}$ \\
\hline Note: drawn up by the author based on Financial Statements of Air Astana JSC \\
\hline
\end{tabular}

Speaking about indisputable advantages of IPO, it should be noted that, in addition to attracting capital, IPO provides the issuing company a number of other unique opportunities for further business development:

- it significantly improves the financial reliability of an issues body;

- it creates conditions for more profitable placement of debt equity securities, as well as for attracting loans secured by shares;

- it promotes effective instrument for assessing the fair market value of the company and beneficial mechanism for mergers/acquisitions;

- it allows the company to strengthen its lobbying capacity through inclusion of influential financial institutions in the membership of shareholders;

- it enhances the prestige of the company as a partner and counterparty when working with domestic and foreign firms [13].

\section{Conclusion}

Summarizing the above, it should be emphasized that digitalization of financial resources at the enterprise, which is the basis for ensuring its financial stability, will facilitate the creation of all opportunities for further financial and economic activity with positive results. At the same time, it should be based on the use of a number of measures: increase of the innovative and intellectual potential of the enterprise; introduction of advanced international experience in the management of material, labour, and financial resources of the enterprise; raising the skills of employees of the enterprise, etc.

Further research should be aimed at developing and implementing an effective innovation policy that can provide long-term competitiveness of domestic enterprises and increase their financial resources.

The availability of sufficient financial resources, their effective use, determine the good financial position of the company, solvency, financial stability, liquidity. In this regard, the most important task of enterprises is to find reserves to increase their own financial resources and their most effective use in order to improve the efficiency of the enterprise as a whole [14].

The article showed that for effective not only economic, but also financial activity of the enterprise as a whole, each business entity must form its own financial management strategy. Practice shows that, as a rule, this strategy is to create financial plans: long-term (more than 1 year), medium-term (annual, quarterly), short-term (monthly).

Management of financial resources of an enterprise is reduced to a continuous process of financial information, its analysis and further development and adoption of management decisions based on the results of analysis. The continuity of the process is determined by the 
presence of: organizational, methodological, personnel, information, technical and regulatory support. One of the most important directions of the financial policy of enterprises in modern conditions is the formation of a strategy for the formation of financial resources, which should be aimed at overcoming unprofitability, reducing financial risks, ensuring the required liquidity, and increasing the efficiency of using their financial potential.

Effective management of the formation and use of financial resources of the enterprise will ensure the growth of wealth of shareholders (owners) of the enterprise as the fundamental goal of financial management, which is manifested in the growth of the value of the enterprise and the creation of added cash value $[15,16,17]$.

The investigation performed has shown that for effective not only economic, but also the financial activity of the enterprise as a whole, each entity must form their own financial management strategy. Practice shows that, as a rule, this strategy is to create financial plans: long-term (over 1 year), medium (annual, quarterly), short-term (monthly). Management of financial resources of an enterprise is reduced to a continuous process of processing financial information, its analysis and further development and adoption of management decisions based on the results of the analysis. The continuity of the process depends on organizational, methodological, personnel, information, engineering and regulatory support. One of the most important directions of the financial policy of enterprises in modern conditions is the formulation of a strategy for development of financial resources, which should be aimed at overcoming unprofitability, reducing financial risks, ensuring the required liquidity, and increasing the efficiency of using their financial strength. Effective management for developing and using the financial resources of the enterprise will ensure the growth of wealth of shareholders (owners) of the enterprise as the fundamental goal of financial management, which is manifested in the growth of the value of the enterprise and creation of added cash value.

\section{References}

1. Ford, A., Freeman, V. A., Generational Income Mobility in North America and Europe, 38-47 (2016)

2. Samuel, A.N., Bulletin of the Economy of Transport and Industry, 29, 65-68 (2010)

3. Douglas, A., Economics: Realities of Time, 6 (16), 217-223 (2014)

4. Blundell, R., Annu. Rev. Econ., 6 (1), 689-733 (2004)

5. Kupeshova, B.K., Saduanova G.M. Korporativnye finansy: prakticheskie kursy dlya studentov ekonomicheskoi specialnosti, 480 (Kazakh University, Almaty 2014)

6. Berger, A., Macroecon. Dyn. 12 (S2), 231-284 (2010)

7. Klomp, J., Haan, J., Financial Planning in Providing Financial Resources at Enterprises, 9-1, Part 3, 112-115 (2014)

8. Busrmistrova L.M., Finansy organizacii: prakticheskie kursy, 240 (INFRA-M, 2016)

9. Tusupbekov T., Tenizbaeva G. Ekonomika kompanii (prakticheskie kursy): uchebnik, 208 (Folio, Astana, 2016)

10. Gilyarovskaya L.T., Kopleksnye ekonomicheskiy analiz hozyaistvennoi deyatelnosti, 388 (Prospect, 2016)

11. Financial statements of Air Astana JSC https://airastana.com/

12. Ghosh, A., Review of Development Finance, 6 (1), 58-70 (2016)

13. Roodman, D., Stiroh, K., Business-inform, 10, 249-255 (2014)

14. Malady, L., Banking\&Finance Law Review, 31 (2), 389-401 (2016)

15. Nickell, S.J., Peculiarities of the Methodological Toolkit for the Study of the FinancialEconomic Resources of Trade Enterprises (2013)

16. Zhanbolatova, A., Ziyadin, S., Zhumanov, K., \& Jumabekova, A., Banks \& bank systems, 13 (1), 98-114 (2018) DOI: 10.21511/bbs.13(1).2018.10 
17. Ziyadin, S., et al., A. The role of social media marketing in consumer behaviour/E3S Web of Conferences (2019) 